\title{
The Significant Role of Islamic Financial Literacy among College Students in Malaysia
}

\author{
Sazana Ab Rahman ${ }^{1 *}$, Anas Tajudin ${ }^{2}$, Ahmad Fadzli Ahmad Tajuddin ${ }^{3}$ \\ ${ }^{I}$ Department of Commerce, Ungku Omar Polytechnic, Ipoh, Perak, Malaysia \\ ${ }^{2}$ Faculty of Management \& Information Technology, Sultan Azlan Shah University, Kuala Kangsar, Perak, \\ Malaysia \\ ${ }^{3}$ The Malaysian Institute of Integrity, Kuala Lumpur, Malaysia
}

*Corresponding Author: Sazana Ab Rahman, Department of Commerce, Ungku Omar Polytechnic, Ipoh, Perak, Malaysia

\begin{abstract}
Islamic financial literacy specifically refers to financial literacy of Islamic financial products and Islamic finance concepts. Currently, even the increased awareness in Islamic finance around the world especially from the Muslim countries, the Islamic financial products are still unclear to some people not only youngsters but also among adults. This paper highlights the significant role of Islamic financial literacy especially among young people. It should be noted that the importance of Islamic financial literacy is difficult to be ignored especially for Muslims. Much of the current works have been on the literacy on conventional financial knowledge. Since there is a renewed interest in Islamic finance, more studies should be undertaken in order to determine the level of literacy of people on Islamic financial concepts and products. This paper represents an initial attempt to explore the concept of Islamic financial literacy among college students. It is hoped that this paper could help other researchers to further expand the knowledge in the area of Islamic financial literacy particularly among college students in Malaysia. The future research should intents to fill in the gap in the study of individual or personal financial literacy in the Islamic context by focusing on younger generation such as college students in Malaysia.
\end{abstract}

Keywords: Financial Literacy, Islamic Financial Literacy, Students Financial Literacy

\section{INTRODUCTION OF ISLAMIC FINANCIAL LITERACY}

Mohomed (2015) explained that since literature on Islamic financial literacy are scarce, no definition was found except for Abdullah \& Anderson (2015) which built on Houston's (2010) definition of financial knowledge stating that Islamic financial knowledge means "the stock of knowledge that one acquires through education and/or experience specifically related to essential Islamic finance concepts and products". Hence, it can be simplified that the definition of Islamic financial literacy specifically refers to financial literacy of Islamic financial products and Islamic finance concepts.

The most important differences between Islamic finance and conventional finance is the prohibition of forbidden elements in the transactions such as Riba (interest), Gharar (uncertainty) and Maysir (gambling). Numerous Islamic instruments are used by Islamic finance categorized as saving (wadiah), sale contracts (Murabahah, Salam, Istisnah), partnership modes (Mudarabah, Musharakah), or hybrid modes (Diminishing Musharakah), amongst others.

Currently, even the increased awareness in Islamic finance such as Islamic Social Finance and Islamic Financial Technology around the world especially from the Muslim countries, the Islamic financial products are still unclear to some people not only youngsters but also among adults. The root for the unclear knowledge among consumers regarding Islamic financial products is normally because of the unclear Islamic concepts in the product's information from one to another. Not to mention that many Muslim consumers themselves are not aware and ignore the importance of Shariah compliant products. Thus, low Islamic financial literacy levels may signify a serious threat to the survival of current and future Islamic products specifically and to the Islamic finance sector in general. As suggested by Mohomed (2015), the need of the consumer protection and financial literacy are vital 
pillars to ensure a sound and stable financial system, which brings us to the realization that there is pressing need for Islamic financial literacy.

Islamic financial literacy is still new issues and can be considered as at developmental stage. Many initiatives have been taken not only by government but also the Islamic financial institutions. For instance, the increasing trend of college/university programs and professional courses related to Islamic finance are offered among many academic institutions in different countries around the world. The active participation in upgrading the Islamic financial education programs not only from financial regulators in Muslim countries such as Malaysia, Indonesia, Brunei, Bahrain, Turkey and Saudi Arabia, but also from non-Muslim countries such as United Kingdom and Japan. For example, a few of Malaysia universities has established a special Waqf fund designated to promote Islamic finance training, education and research. However, according to Mohomed (2015), the success and outreach of these Islamic financial literacy projects are yet to be established.

Unfortunately, despite the importance of financial literacy, research has shown that this ability among the people of the world, especially in developing and underdeveloped countries is not perfect and barriers such as the complexity of financial life, the existence of many options when making decisions and having not enough time and money to learn about personal finance issues, caused low financial literacy of people in these communities (Taft, Hosein, \& Mehrizi, 2013).The increasing attention to the significant role of financial literacy is attributed to the rising level of indebtedness among the young people (Hafizah, et al 2016).

Taft, Hosein, \& Mehrizi (2013) stated that in the 2015 financial inclusion survey by the World Bank, data study performed and announced in 147 countries on behalf of $97 \%$ of the world population, the rate of financial exclusion due to religious reasons worldwide was calculated to be $7 \%$ while this rate was revealed to be $9.7 \%$ in D-8 countries (Bangladesh, Indonesia, Iran, Malaysia, Egypt, Nigeria, Pakistan and Turkey; Iran wasn't included into the data pool). Islamic banks appear to be the most important interface for increasing the tendency of individuals with religious sensitivity for financial inclusion by rendering services like deposit banks in accordance with religious principles for such persons (Taft et al., 2013). It is very important to conduct a research for the purpose of more understanding regarding the İslamic financial literacy level of individuals with religious sensitivity for the purpose of increasing their financial inclusion. However, a tool for measuring Islamic financial literacy level has not been tested yet.

The aftermath of 2008 Great Recession, numerous studies were undertaken by academic researchers in analyzing the factors affecting the financial literacy of individuals such as worker, retiree or student. Lusardi et al.'s (2010) study revealed that financial literacy among the young was low and strongly related to socio-demographic characters and family financial sophistication. While many studies have been published on corporate financial decision making and asset pricing, few studies have addressed personal financial literacy (Kehiaian, 2012). Low financial literacy is found among consumers in many countries (Lusardi \& Mitchell 2014).

Categorized as one of the developing countries, Malaysia is not missed being one of the regions whereby financial literacy level is at the bottom end (Ibrahim, Harun, \&Mohamed, 2009). Prior to millennium era, percentage of society knowledge on issues such as budgeting, saving, investing and insuring were minimal. Of course, those who do study on the financial matter or seeking for financial professional advice are normally among professionals, semiprofessionals or those who are familiar with financial management. There are almost no programs or seminars targeting those of children and young adults except if they undergo certain financial courses during their academic studies at college/university level. As a consequence, the literacy and understanding level of finance among these young groups is very limited except for what they have learned directly or indirectly through experience, family or even peers. There is obviously more to be covered regarding the determinant factors that influence the financial literacy among college students in Malaysia. (Sabri, 2011). Ahsan (2013) concludes that all four studies he reviewed unanimously agreed that financial literacy level was low for Malaysian university students. Thus, the future research should intents to fill in the gap in the study of individual or personal financial literacy in the Islamic context by focusing on younger generation such as college students in Malaysia.

The Central Bank of Malaysia's Governor highlighted the importance of Islamic financial literacy in easing transactions and increasing acceptability of Islamic financial products (Mohomed, 2015). 
According to Abdullah\& Chong (2014), more research on Islamic financial literacy is required. In Malaysia, the only works found in this area are Abdullah \& Anderson (2015), Hafizah, et al. (2016) and Abdul Rahim et al. (2016). Therefore, the future research should be undertaken to fill in the lack of research in Islamic financial literacy in Malaysia, particularly focus on the young generation such as college students and university students in Malaysia.

\subsection{The Relationship of Financial Literacy with Islamic Context}

It should be emphasized that Islamic financial literacy is a religious duty for every Muslim because it carries further implications on the realization of Al-Falah (true success) not only in this world but also in the hereafter. In particular, a Muslim must be knowledgeable with the various rules and regulations governing his economic and financial dealings. However, the existence of certain unlawful elements such as interest, uncertainty and gambling, the existing financial literacy constructs which are not in line with the underlying philosophy of Islamic finance highlights the crucial need to develop the constructs for assessing Islamic financial literacy.

According to Idris et al. (2013), preferences for lavish lifestyle have led them to spending beyond limits to the point that they are willing to be in debt. This is contrary to the teachings of Islam which promotes moderation in spending as well as limiting the use of debt only for genuine needs (Hafizah et al., 2016). This is contrary to the Islamic teaching which promotes moderation in spending as well as limiting the use of debt only for genuine needs. A hadith narrated by Imam Ahmad, where the Prophet Muhammad (p.b.u.h) was reported to have said: "Be wary of debts, indeed it is sadness at night and a disgrace in the day" stresses that being in debt not only leads to increase in financial burden, but it can also cause emotional burden. This explains why the concept of moderation in spending is highly encouraged in the Quran, as stated in chapter Al-Furqan verse 67 which means: "Those who, when they spend are not extravagant and not niggardly, but hold a just (balance) between those (extremes)." At that point, it would not be much of an optimistic approach to expect from the consumers without sufficient knowledge even on the existing system in the world to display conscious behaviors regarding the Islamic financial products, which is a new financial method, or Islamic financial method and tools.

Previous studies conducted in Malaysia found that low level of financial literacy among college/university students are attributed to weak money management skills. Particularly, most of them tend to spent aggressively for non-academic purposes and are not likely to save upon receiving their scholarship or student loan. In view of these concerns, this paper focus on assessing Islamic financial literacy among college/university students. Specifically, Islamic financial literacy is considered a new area with very limited literature. More importantly, despite calls for such attempt in the literature, the constructs for Islamic financial literacy have not been adequately examined (Abdullah \& Anderson, 2015). Much of the current works have been on the literacy on conventional financial knowledge. Since there is a renewed interest in Islamic finance, more studies should be undertaken in order to determine the level of literacy of people on Islamic financial concepts and products. Researchers should also look into the designing instruments to measure the level of Islamic financial literacy (Abdullah \& Chong, 2014).

\section{SignifiCANCE OF THE ISLAMIC FinANCIAL LiTERACY}

The consequences of not knowing even the basics about household financial matters can prove to be costly for adults as they make financial decisions for the short term or the long term. It is this ever changing and costly financial environment that has stimulated major interest in financial literacy in recent decades. This growing interest has led to increased research among economists and other academics on how financial literacy affects the financial decision making of both adults and youth and their financial capabilities.

Measuring financial literacy with just a test score and then using it to assess the effects of financial literacy on financial decision making may understate the contribution that financial literacy makes to that financial behavior. Future research should consider both what people know about financial matters and also what they think they know when controlling for financial literacy. Both financial knowledge and perception appear to affect financial literacy and in turn appear to affect financial decisions and behavior (Allgood \& Walstad, 2016). The significance of the future research is that it may create new knowledge about Islamic financial literacy determinants among youth. The future 
research will add to previous research on the topic of financial literacy in the Islamic context. The research study may contribute to the knowledge regarding the awareness of financial literacy that may assist with managing the personal finance and future business finances.

Moreover, studying the level of Islamic financial literacy among students could help economic development of the societies. For instance, the research that highlights the importance of Islamic financial literacy among students and then in sustainable development of societies. It indicates that there are still not enough studies about teaching that significant skills to this important group for societies progress. On the other hand, there is a limited number of empirical studies on the Islamic financial literacy while a great variety of researches were done on conventional financial literacy. As the standard of living among Malaysians has improved significantly and stimulated changing lifestyles, college students today are granted greater freedom from their parents to make their own shopping and consumption decisions. Inadequate knowledge of personal finance may increase conspicuous consumption and lead to poor financial management ( Sabri, 2011). Due to the small sample size, future studies should include a larger sample that includes a diverse sample (Nguyen, 2013). The universal effectiveness of financial literacy programs remains widely unknown (Nguyen, 2013). Youth still demonstrate low levels of financial literacy even after completing a financial literacy class. Therefore, further research should continue evaluating students' financial literacy in multiple waves to determine whether their literacy was retained. This would also examine whether students are able apply their financial knowledge into the real world. This paper highlights the significant role of Islamic financial literacy especially among young people. It should be noted that the importance of Islamic financial literacy is difficult to be ignored especially for Muslims. This paper represents an initial attempt to explore the concept of Islamic financial literacy among college students. It is hoped that this paper could help other researchers to further expand the knowledge in the area of Islamic financial literacy particularly among college students in Malaysia.

\section{CONTRIBUTION}

The main objective of this paper is to assess the important of Islamic financial literacy for different target populations which is young adult specifically students at college level since students are our industry's potential that is very important for future economy development. The development of validated constructs for Islamic financial literacy is crucial since most contemporary research only focuses on conventional financial literacy which contains some elements that are not compatible with the principles of Islamic teaching.

\section{REFERENCES}

[1] Abdul Rahim, et al (2016), Islamic Financial Literacy and It's Determinants Among University Students: An Exploratory Factor Analysis", International Journal of Economics and Financial Issues, Vol.6, No. S7, pp.32-35.

[2] Abdullah \& Anderson (2015). Islamic Financial Literacy among Bankers in Kuala Lumpur. Journal of Emerging Economies and Islamic Research, 3(2). Retrieved from www.jeeir.com.

[3] Abdullah \& Chong. (2014). Financial Literacy: An Exploratory Review of the Literature and Future Research. Journal of Emerging Economies and Islamic Research, 2(3), 1-9. Retrieved from http://www.jeeir.com/v2/images/Vol2No32014/129-284-1-PB.pdf.

[4] Ahsan, M.H., (2013). Financial Literacy Research on Undergraduate Students in Malaysia: Current Literature and Research Opportunities. International Journal of Education and Research, 1 (11).

[5] All good, S., \& Walstad, W. B. (2016). The Effects of Perceived and actual Financial Literacy on Financial Behaviors. Economic Inquiry, 54(1), 675-697. https://doi.org/10.1111/ecin.12255.

[6] Hafizah, et al. (2016). Islamic Financial Literacy and its Determinants among University Students: An Exploratory Factor Analysis. International Journal of Economics and Financial Issues, 6(S7), 32-35. Retrieved from http: www.econjournals.com.

[7] Huston, S. (2010). Measuring financial literacy. Journal of Consumer Affairs, 44(2), 296-316. Retrieved from http://onlinelibrary.wiley.com/doi/10.1111/j.1745-6606.2010.01170.x/full.

[8] Ibrahim, D., Harun, R., \& Mohamed I, Z. (2009). A Study on Financial Literacy of Malaysian Degree Students. Canadian Academy of Oriental and Occidental Culture Cross-Cultural Communication, 5(4), 51-59.

[9] Idris, et al. (2013). Relationship between Financial Literacy and Financial Distress Among Youths In Malaysia -An Empirical Study. Malaysian Journal of Society and Space, 9(4), 106-117. 
[10] Kehiaian, S. E. (2012). Factors and Behaviors That Influence Financial Literacy In US Households. Southeastern University. Retrieved from UMI 3517279 Copyright 2012 by ProQuest LLC.

[11] Lusardi, A., Mitchell, O., (2014), 'The Economic Importance of Financial Literacy: Theory and Evidence', Journal of Economic Literature, Vol: 52 (1): 5-44. DOI: http://dx.doi.org/10.1257/jel.52.1.5.

[12] Lusardi, A., Mitchell, O.S., \& Curto, V. (2010). Financial literacy among the youth. The Journal of Consumer Affairs, 44(2), 358-380. doi: 10.1111/j.1745-6606-2010. 01173.

[13] Mohomed, N (2015). Islamic Financial Literacy Among QFIS Students. Hamad Bin Khalifa University.

[14] Nguyen, K. N. (2013). High School Seniors Financial Knowledge: The Impact of Financial Literacy Classes and Developmental Assets. University of Arkansas. Retrieved from http://scholarworks.uark.edu/ etd/867.

[15] Sabri, M.F (2011). Pathways to financial success: Determinants of financial literacy and financial wellbeing among young adults. Graduate Theses and Dissertations. Paper 11205. IOWA State University. Retrieved from http://lib.dr.iastate.edu/etd.

[16] Taft, M., Hosein, Z., \& Mehrizi, S. (2013). The relation between financial literacy, financial wellbeing and financial concerns. International Journal of Business and Management, 8(11), 63-75. Retrieved from http://www.ccsenet.org/journal/index.php/ijbm/article/viewFile/24940/16664.

Citation: Sazana Ab Rahman, Anas Tajudin, Ahmad Fadzli Ahmad Tajuddin. " The Significant Role of Islamic Financial Literacy among College Students in Malaysia" International Journal of Managerial Studies and Research (IJMSR), vol 6, no. 11, 2018, pp. 46-50. doi:http://dx.doi.org/10.20431/2349-0349.0611005.

Copyright: (C) 2018 Authors. This is an open-access article distributed under the terms of the Creative Commons Attribution License, which permits unrestricted use, distribution, and reproduction in any medium, provided the original author and source are credited. 